\title{
Kesiapan Guru Dan Peserta Didik Dalam Pembelajaran Daring Di SD Inpres Lae-Lae 2 Kota Makassar
}

\section{The Readiness of Teachers and Students in Online Learning at SD Inpres Lae-lae 2 Makassar City}

\author{
Mudrifah ${ }^{1}$, Sundari Hamid ${ }^{2}$, Syahria Majid ${ }^{2}$ \\ ${ }^{1}$ Sekolah Dasar Negeri Lae-Lae II Kota Makassar \\ ${ }^{2}$ Program Studi Pendidikan Dasar Pascasarjana Universitas Bosowa \\ "E-mail: ifahmudrifah@gmail.com
}

Diterima: 19 September 2021/Disetujui 24 Desember 2021

\begin{abstract}
Abstrak. Penelitian ini bertujuan untuk mengetahui kesiapan guru dan peserta didik dalam pembelajaran daring di SD Inpres Lae-Lae 2, serta mengetahui proses pembelajaran daring di SD Inpres Lae-Lae 2. Dalam penelitian ini menggunakan penelitian kualitatif dengan metode studi kasus. Subjek penelitian ini adalah guru dan peserta didik kelas IV. Pengumpulan data diambil melalui observasi, wawancara, dokumentasi. Penulis berperan sebagai pewawancara langsung untuk menggali data melalui guru dan peserta didik kelas IV. Hasil penelitian kesiapan guru dalam pembelajaran daring pada masa pandemi covid-19 di SD Inpres Lae-Lae 2 ini menunjukkan terlaksana dengan baik. Walaupun pembelajaran ini dilakukan dengan daring, guru tetap membuat RPP, mempersiapkan bahan ajar dan media pembelajaran sebelum memulai proses pembelajaran. Dalam pelaksanaan pembelajaran daring kesiapan peserta didik juga sudah terlaksana dengan baik, karena mereka sudah mempersiapkan apa saja yang dibutuhkan dalam pembelajaran daring, seperti buku, pulpen, dan handphone. Dalam pelaksanaan proses pembelajaran daring ini aplikasi yang digunakan adalah whatsapp dan zoom, adapun kendala yang ditemukan guru dan peserta didik yaitu kurang stabilnya jaringan internet sehingga mengalami kesulitan dalam belajar.
\end{abstract}

Kata Kunci: Guru, Peserta Didik, Pembelajaran Daring.

\begin{abstract}
This study aims to determine the readiness of teachers and students in online learning at SD Inpres Lae-Lae 2, and to determine the online learning process at SD Inpres Lae-Lae 2. This study is qualitative research with a case study method. The subjects in this study were teachers and fourth grade students. Data collection was taken through observation, interviews, and documentation. The author acts as a direct interviewer to collect data through teachers and fourth grade students. The results showed that the readiness of teachers in online learning during the Covid-19 pandemic at the Inpres Lae-Lae 2 Elementary School was carried out well. Although learning is done online, the teacher continues to plan learning by making online lesson plans, preparing teaching materials in the form of learning media and preparing teaching materials before the learning process takes place. In the implementation of this online learning process, the applications used are whatsapp and zoom, while the obstacles found by teachers and students are the unstable internet connection so that they experience difficulties in learning.
\end{abstract}

Keywords: Teachers, Students, Online Learning.

(c) ()

\section{Pendahuluan}

Pendidikan merupakan salah satu indikator utama pembangunan dan kualitas sumber daya manusia, sehingga kualitas sumber daya manusia sangat tergantung dari kualitas pendidikan. Tanpa pendidikan manusia akan merasa sulit berkembang juga terbelakang karena masalah pendidikan ini adalah hal yang sangat penting dalam kehidupan manusia, dengan demikian pendidikan harus diarahkan untuk menghasilkan manusia yang berkualitas, mampu bersaing, memiliki budi pekerti yang luhur dan moral yang baik (Triwiyanto, 2017).

Di era serba digital ini, guru juga dituntut dapat menguasai teknologi informasi dan komunikasi. Kalau guru gagal teknologi maka guru akan mengalami kesulitan dalam mengembangkan kemampuannya( Suyono, 2019). Tidak sama dengan 10 atau 20 tahun lalu yang sumber belajarnya sangat terbatas dan baru hanya bersumber pada buku dan guru di sekolah. Saat ini sumber belajar sudah banyak, mulai dari buku, televisi, radio, sampai internet. Dengan adanya handphone, internet sudah bisa masuk kedalam rumah kita dengan mudah (Suyono, 2019).

Perkembangan pendidikan saat ini dipengaruhi oleh pesatnya kemajuan teknologi informasi dan komunikasi. Salah satu teknologi informasi yang ikut berperan dalam dunia pendidikan yaitu pembelajaran daring (Musdar dan Muriati, 2019). Pembelajaran daring berfungsi sebagai penghubung antar pendidik dengan siswanya dengan jaringan internet yang dapat diakses kapan saja dan dimana saja. Media daring yang digunakan seperti WhatsApp, Google Classroom, Website. 
PJJ merupakan proses belajar mengajar yang dilakukan secara jarak jauh melalui penggunaan berbagai media komunikasi, dijelaskan dalam Undang-Undang Perguruan Tinggi nomor 12 tahun 2012, pasal 31 tentang Pendidikan Jarak Jauh (PJJ). PJJ bertujuan untuk memberikan layanan pendidikan tinggi kepada kelompok masyarakat yang tidak bisa mengikuti pendidikan secara tatap muka dan memperluas akses dan mempermudah layanan pendidikan tinggi dalam pendidikan dan pembelajaran, dijelaskan dalam Permendikbud No. 109/2013 (Pasal 2). Dengan itu bisa di artikan bahwa PJJ adalah suatu sistem pendidikan yang mempunyai karakteristik terbuka, belajar mandiri, dan belajar tuntas dengan memanfaatkan teknologi.

Dengan adanya PJJ ini orang bisa menghasilkan akses dalam pendidikan yang berkualitas, contohnya pendidikan tatap muka pada umumnya tanpa dia meninggalkan keluarga atau rumah dan kampung halaman serta pekerjaan. Dalam sistem PJJ juga diharapkan bisa meningkatkan pemerataan kualitas pendidikan untuk setiap orang. Sistem PJJ dalam mendistribusikan pendidikan berkualitas yang berstandar dengan memanfaatkan teknologi informasi dan komunikasi, standar pencapaian pembelajaran, materi ajar, proses pembelajaran, dan evaluasi pembelajaran menjadikan pendidikan berkualitas bisa diperoleh berbagai kalangan lintas ruang dan waktu.

Pembelajaran Jarak Jauh (PJJ) tidak mudah dilakukan, sangat berbeda jauh dengan pembelajaran tatap muka. Perbedaan yang paling mendasar yaitu peserta didik tidak bisa melakukan interaksi langsung dengan guru (Teguh, 2015). Sehingga komunikasi yang terjalin sangatlah terbatas. Keterbatasan komunikasi ini menyebabkan terjadinya keterbatasan dalam menangkap informasi yang diberikan oleh guru.

Salah satu cara untuk mengatasi masalah pendidikan pada saat ini ialah e-lerning, pada negara maju ataupun negara yang sedang berkembang, seperti negara kita ini. Kebanyakan yang menggunakan istilah berbeda untuk $e$-learning tapi, $e$ learning merupakan pembelajaran yang memakai jasa elektronik sebagai alat bantunya. Dalam pembawaan materi dengan daring dapat bersifat interaktif sampai peserta didik bisa berinteraksi dengan komputer sebagai media belajarnya. Salah satu contoh peserta didik yang menggunakan pembelajaran media elektronik atau browsing, chatting, videocall, melalui media elektronik yaitu komputer dan internet akan mendapatkan hasil belajar yang lebih efektif.

Penggunaan media pembelajaran dalam proses belajar mengajar adalah salah satu upaya yang bisa meningkatkan efektivitas dan kualitas proses pembelajaran yang dapat meningkatkan kualitas hasil belajar peserta didik. Ketika guru tidak dapat hadir, guru bisa memantau peserta didik lewat pembelajaran daring atau memberikan materi serta tugas yang bisa memberikan umpan balik dengan cepat. Adapun pembelajaran daring bisa digunakan untuk program pengayaan untuk peserta didik yang kurang memahami materi yang disampaikan oleh guru.

Dengan adanya kelebihan yang didapatkan dalam pembelajaran daring, ada juga beberapa kekurangan pembelajaran daring yaitu kurang bersosialisasi antara guru dengan peserta didik, antara peserta didik dengan peserta didik lainnya (Rahyuni, 2021). Karena dalam proses pembelajaran yang dilakukan secara daring bisa diartikan letak geografis yang tidak sama dari setiap pengguna. Dengan itu bisa diatasi dengan tidak menghapuskan pembelajaran di kelas serta memberikan tugas kelompok dalam kelas daring sehingga peserta didik tetap bisa saling berkomunikasi dan berbagi pendapat. Tetapi tidak semua pembelajaran daring bisa langsung diajarkan dalam suatu lingkungan sekolah, berhasil tidaknya pencapaian tujuan pendidikan banyak tergantung pada proses belajar yang di alami peserta didik.

Dalam pandemi covid-19 telah menemukan kendala semua kalangan di dunia dan menjadikan krisis kesehatan bagi manusia. Dalam dunia pendidikan, pandemi covid-19 juga memberikan dampak yang luar biasa karena banyak sekolah yang telah ditutup untuk menghentikan penyebaran covid-19, peserta didik jadi terganggu dalam aktivitas belajarnya karena sekolah telah ditutup. Adapun dampak covid-19 dalam dunia pendidikan sangat besar dan sangat dirasakan terutama guru, kepala sekolah, peserta didik dan orang tua. Karena dengan dilakukannya penutupan sekolah, maka pemerintah lalu mengambil langkah supaya proses pembelajaran tidak tertinggal dan peserta didik tetap mendapatkan ilmu. Dalam keputusan pemerintah selanjutnya adalah proses pembelajaran tetap berlangsung tetapi tidak melalui tatap muka, namun melalui pembelajaran daring.

Simmons (2002) menjelaskan bahwa banyak organisasi menggunakan metode penyampaian untuk pelatihan pegawai dengan pembelajaran daring. Karena adanya peraturan ini, guru harus bisa melakukan proses pembelajaran dengan efektif secara daring di rumah. Guru di tuntut untuk bisa menggunakan pengajaran secara daring, kemampuan guru dalam teknologi informasi sangat dibutuhkan. Guru juga dituntut untuk merombak kembali rencana pembelajaran dengan metode daring sehingga proses dalam pembelajaran ini efektif dan ilmu bisa tersampaikan.

Covid-19 merupakan masalah yang berdampak bagi guru dan peserta didik, karena pembelajaran yang biasanya dilakukan di dalam ruangan kelas dan suasana yang banyak orang, tetapi harus berbanding terbalik karena belajar di rumah saja. Dan dengan melihat kemampuan dan kualitas peserta didik sangat berbeda dan daya serap peserta didik juga berbeda. Maka dengan ini akan memiliki dampak dengan prestasi peserta didik dan juga motivasi di dalam proses pembelajaran. Dalam situasi ini juga sangat berdampak kepada orang tua, karena mereka kembali mendapatkan tugas tambahan dan juga menjadi guru buat anaknya selama proses pembelajaran daring ini berlangsung.

Tanggung jawab dan peran orang tua di dalam pembelajaran anak sangat berpengaruh pada era pandemi covid-19 ini, dikarenakan sebagian tugas dari guru telah dilakukan oleh para orang tua peserta didik. Kalau melihat penjelasan mengenai pandemi covid-19 dalam proses pembelajaran bagi guru dan peserta didik tersebut banyak permasalahan dan kondisi yang memaksakan guru dan peserta didik serta orang tua untuk melakukan pembelajaran daring.

Adapun beberapa faktor pendidik ialah salah satunya terkait dengan sistem pembelajaran yang disiapkan dalam proses mengajar, faktor peserta didik salah satunya berkaitan erat dengan kesiapan proses belajar mengajar, karena jika tidak ada kesiapan dari peserta didik, maka sistem pembelajaran yang diterapkan bisa berpengaruh buruk dalam proses belajar mengajar (Asmani, 2016). Pada lingkungan sekolah, peserta didik melakukan interaksi secara langsung dengan guru sehingga banyak pengetahuan guru tentang peserta didiknya. 
Berdasarkan hasil observasi yang dilakukan di SD Inpres Lae-lae 2 Kota Makassar, sekolah ini belum memiliki fasilitas internet. Adapun dalam tingkat kesiapan dalam pembelajaran daring yang akan diterapkan, maka sekolah bisa menentukan langkah selanjutnya yang diambil. Adapun tingkat kesiapan dalam setiap kategori dapat yang diuji bisa mengetahui tingkat kesiapan secara keseluruhan.

Sehingga sekolah bisa menghemat karena hanya akan memberikan waktu dengan melakukan sosialisasi atau pelatihan dan langkah yang lainnya. Dari penjelasan diatas diperlukan kesiapan guru serta peserta didik dalam pembelajaran daring di SD Inpres Lae-Lae 2 Kota Makassar.

\section{Metode Penelitian}

\section{a. Jenis Penelitian}

Penelitian ini menggunakan pendekatan penelitian kualitatif dengan metode studi kasus. Bogdan dan Tailor (Moleong, 2007) menjelaskan bahwa penelitian yang menggunakan metode kualitatif menghasilkan data deskriptif, kata-kata yang tertulis atau lisan dari orang-orang serta perilaku yang bisa diamati.

\section{b. Lokasi dan Waktu Penelitian}

Lokasi yang dijadikan penelitian adalah SD Inpres Lae-Lae 2 Kota Makassar. Penelitian ini dilakukan pada bulan April 2021.

\section{c. Fokus dan Deskripsi Penelitian}

Berdasarkan dalam rumusan masalah ini, maka fokus penelitian ini meliputi kesiapan guru, kesiapan peserta didik, dan proses pembelajaran daring.

\section{d. Instrumen Penelitian}

Instrumen penelitian berupa pertanyaan-pertanyaan terstruktur untuk dijadikan bahan data atau sumber yang relevan dalam penelitian. Peneliti melakukan wawancara dengan guru dan peserta didik SD Inpres Lae-Lae 2, pertanyaan berjumlah 15 berfokus terhadap penelitian kesiapan guru yang berjumlah 3 orang dan siswa kelas IV yang berjumlah 5 orang dalam proses pembelajaran daring. Berdasarkan teori kesiapan maka angket disusun sendiri oleh peneliti sesuai dengan keperluan penelitian.

\section{e. Teknik Pengumpulan data}

Pada penelitian ini menggunakan metode pengumpulan data yaitu observasi, wawancara, dan dokumentasi.

\section{f. Teknik Analisis Data}

Sesuai dengan tujuan penelitian sehingga teknik analisis data yang digunakan untuk menganalisis data dalam penelitian ini adalah analisis kualitatif seperti yang diajukan oleh Miles dan Huberman (1992) adalah:

1. Pengumpulan Data / Data Collection yaitu data yang diperoleh dari hasil observasi, wawancara dan dokumentasi.

2. Mereduksi Data / Data Reduction merupakan proses seleksi, pemfokusan, penyederhanaan dan abstraksi.

3. Penyajian Data / Data Display ialah sekumpulan informasi yang tersusun sehingga memberikan kemungkinan penarikan kesimpulan dan pengambilan tindakan.

4. Penarikan Kesimpulan (Conclusions/Verifying) ialah usaha untuk mencari dan memahami makna, keteraturan polapola penjelasan, alur sebab akibat atau proposisi.

\section{g. Pengujian Keabsahan Data}

Pada penelitian kualitatif, peneliti menguji keabsahan data yang akan menggunakan teknik triangulasi. Triangulasi dalam pengujian kredibilitas ini ialah sebagai pengecekan data, dengan demikian terdapat 2 macam triangulasi yaitu triangulasi sumber dan triangulasi waktu.

\section{Hasil dan Pembahasan}

\section{Kesiapan Guru Dalam Pembelajaran Daring}

Dalam pembelajaran daring pada masa pandemi covid-19 di Sekolah Dasar Inpres Lae-Lae 2 tepatnya dikelas IV sudah terlaksana dengan baik. Pada pembelajaran daring, guru sudah membuat perencanaan pembelajaran dengan membuat RPP daring dengan berdiskusi bersama guru lain dan melihat dari internet, RPP daring yang dibuat oleh guru terdiri dari kegiatan pendahuluan, kegiatan inti dan penutup. Selain itu guru juga telah mempersiapkan bahan ajar dan media sebelum pembelajaran daring berlangsung. Perencanaan pembelajaran adalah komponen yang sangat penting dalam proses pembelajaran, karena dengan adanya perencanan yang baik maka proses pembelajaran akan menjadi lebih terarah. Pelaksanaan pembelajaran daring yang dilakukan dengan menggunakan aplikasi WhatsApp dan Zoom. WhatsApp digunakan untuk berkomunikasi dengan peserta didik dan orang tua mengenai pelaksanaan pembelajaran dan untuk mengirimkan informasi tentang pembelajaran. Dalam pelaksanaan pembelajaran daring guru juga menggunakan video pembelajaran dari internet atau membuat sendiri video pembelajaran lalu di kirim melalui WhatsApp, agar penggunaan media pembelajaran ini mempermudah peserta didik dalam memahami materi pembelajaran yang disampaikan. Media pembelajaran merupakan alat 
bantu yang digunakan untuk mempermudah peserta didik dalam memahami materi pembelajaran. Pada pelaksanaan pembelajaran daring, guru menggunakan metode ceramah dan penugasan karena dirasa paling efektif dalam menyampaikan materi pembelajaran kepada peserta didik. Untuk hal ini bertujuan mengetahui sejauh mana pemahaman peserta didik terhadap materi yang sudah diajarkan.

\section{Kesiapan peserta didik dalam pembelajaran daring}

Pada pelaksanaan pembelajaran daring, kesiapan peserta didik sudah baik, karena mereka sudah mempersiapkan apa saja yang dibutuhkan dalam pembelajaran daring seperti buku, pulpen, handphone dan dibantu oleh orang tua mereka dalam mempersiapkannya. Begitu juga dengan guru yang telah melakukan persiapan dalam pembelajaran daring, dalam pelaksanaan pembelajaran daring guru juga melakukan pendekatan dalam pembelajaran berupa pemberian motivasi agar semangat belajar, agar peserta didik tetap aktif pada saat proses pembelajaran walaupun dilakukan dengan daring. Dalam pembelajaran daring sangat dibutuhkan motivasi dan dorongan yang kuat sehingga peserta didik tetap semangat dalam belajar. Tetapi sarana dan prasarana dalam pembelajaran daring di sekolah belum terpenuhi karena sekolah belum memberikan fasilitas berupa wifi, biasanya peserta didik terkendala jaringan internet, karena kalau mati lampu maka jaringan dirumah mereka menjadi terganggu. Dalam pelaksanaan pembelajaran ini peserta didik lebih suka menggunanakan handphone karena lebih mudah dan praktis, karena dalam pelaksanaan pembelajaran daring ketersediaan sarana dan prasarana merupakan hal yang penting untuk menunjang keberhasilan pelaksanaan pembelajaran daring. Pada pelaksanaan pembelajaran daring, guru dan peserta didik sudah bisa menggunakan handphone sehingga mereka tidak kesulitan dalam pembelajaran daring, dan kebanyakan peserta didik sudah terbiasa menggunakan handphone. Dalam pelaksanaan pembelajaran daring ini guru dan peserta didik sudah mulai terbiasa dalam melaksanakan pembelajaran. Pelaksanaan pembelajaran daring di Sekolah Dasar Inpres Lae-Lae 2 memiliki kelebihan dan kekurangan, kelebihan dalam pembelajaran daring ini guru menjadi lebih kreatif dan mampu menggunakan media elektronik dalam pembelajaran. Sedangkan kekurangan pembelajaran daring ini yaitu peserta didik mengalami kendala yaitu tidak semua peserta didik dapat dengan mudah memahami materi pembelajaran yang disampaikan oleh guru, karena setiap peserta didik memiliki karakteristik yang berbeda ada yang cepat menangkap materi pembelajaran dan ada juga yang lambat memahami materi, siswa yang tidak memiliki keterampilan dasar serta kedisiplinan yang tinggi akan lebih baik menggunakan pembelajaran secara konvensional karena mereka akan kesulitan dalam memahami materi, sedangkan peserta didik yang memiliki kedisiplinan dan kepercayaan diri akan mampu untuk melaksanakan pembelajaran secara daring.

\section{Proses pembelajaran daring}

Pada proses pelaksanaan pembelajaran daring guru menggunakan aplikasi Whatsapp dan Zoom. Whatsapp yang digunakan untuk berkomunikasi dengan orang tua peserta didik dan peserta didik. Melalui Whatsapp guru memberikan arahan dan informasi mengenai pelaksanaan pembelajaran daring. Adapun metode yang digunakan dalam pembelajaran daring ini adalah ceramah dan penugasan. Metode ceramah digunakan untuk menjelaskan materi yang akan dipelajari oleh peserta didik sehingga peserta didik akan lebih mudah memahami materi pembelajaran, di akhir pembelajaran biasanya guru akan memberikan tugas sebagai latihan dari materi yang sudah dipelajari, namun tugas yang diberikan tidak seperti pada pembelajaran tatap muka. Adapun media pembelajaran yang digunakan berupa video yang buat atau didownload dari Youtobe. Video pembelajaran yang digunakan dalam pembelajaran selalu disesuaikan dengan materi pembelajaran. Meskipun pembelajaran dilakukan secara daring tetap dibutuhkan media pembelajaran untuk mempermudah peserta didik memahami materi yang disampaikan.

\section{Kesimpulan dan Saran}

Kesiapan guru dalam pembelajaran daring pada masa pandemi Covid-19 di Sekolah Dasar Inpres Lae-Lae 2 terlaksana dengan baik. Walaupun pembelajaran dilakukan secara daring guru tetap melakukan perencanaan pembelajaran dengan membuat RPP daring, mempersiapkan bahan ajar dan media pembelajaran. Dalam pelaksanaan pembelajaran guru menggunakan media berupa video, selain itu guru juga menggunakan metode ceramah dan penugasan, dalam penilaian dan evaluasi guru menggunakan aplikasi Whatsapp, untuk mengirim kembali tugas peserta didik yang telah dikoreksi. Selain itu guru juga memberikan penilaian tentang kedisiplinan peserta didik dalam mengumpulkan tugas.

Dalam pelaksanaan pembelajaran daring, kesiapan peserta didik sudah baik, mereka mempersiapkan segala sesuatu yang dibutuhkan dalam pembelajaran daring seperti buku, pulpen, dan handphone. Adapun ditemukan kendala dalam pelaksanaan pembelajaran daring ini yaitu tidak stabilnya jaringan internet sehingga terkadang peserta didik kesulitan untuk belajar. Selain itu, peserta didik juga terkadang mengalami kesulitan dalam memahami materi pembelajaran, namun guru selalu memberikan waktu lebih dengan menanyakan kepada peserta didik jika memang masih ada peserta didik yang belum mengerti tentang materi tersebut maka guru akan dengan sabar memberikan penjelasan ulang.

Pada proses pelaksanaan pembelajaran daring yang guru gunakan adalah aplikasi Whatsapp dan Zoom. Whatsapp digunakan untuk berkomunikasi dengan peserta didik. Melalui Whatsapp guru memberikan arahan dan informasi mengenai pelaksanaan pembelajaran daring. Sekolah lebih memfasilitasi guru dalam pelaksanaan pembelajaran terutama pada pelaksanaan pembelajaran daring seperti sekarang ini. Guru dapat lebih mengembangkan pembelajaran yang dapat membuat kondisi belajar tetap efektif walaupun dilakukan dalam jaringan, lebih sering berkomunikasi dengan peserta didik. Peserta didik lebih diberikan motivasi dalam belajar agar pada saat pelaksanaan belajar melalui dalam jaringan peserta didik tetap memiliki semangat yang tinggi dan dapat mengikuti proses pembelajaran dengan baik sesuai dengan tujuan pembelajaran yang akan dicapai di kelas. 


\section{Daftar Pustaka}

Asmani, Jamal Ma'mur. 2016. Tips Efektif Cooperative Learning.Yogyakarta. Diva Prss

Perkemendikbud Nomor 109/2013 Pasal 2 Tentang Pendidikan Jarak Jauh.

Musdar, I. A. (2019). Pemanfaatan Google For Education (Gafe) Di Smkn 10 Jeneponto. Klasikal: Journal Of Education, Language Teaching And Science, 1(3), 64-74.

Rahyuni, R., Yunus, M., \& Hamid, S. (2021). Pengaruh Game Online Terhadap Motivasi Belajar dan Prestasi Belajar Siswa SD Kecamatan Pammana Kabupaten Wajo. Bosowa Journal of Education, 1(2), 65-70.

Sugiyono. (2013). Metode Penelitian Kuantitatif Kualitatif dan R\&D. Bandung: Alfabeta.

Suyono. 2019. Belajar dan Pembelajaran. Bandung: PT. Remaja Rosdakarya Offset.

Simmons, D. E. (2002). The Forum Report: E-learning Adoption Rates and Barriers. The ASTD e-Learning.

Moleong, L. J. (2007). Metode Penelitian Kualitatif. Bandung: PT Remaja Rosdakarya Offset.

Teguh, M. (2015) "Disfusi Inovasi dalam Program Pembelajaran Jarak Jauh di Yayasan Terampil Indonesia. Lembaga Peneltian dan Pengabdian Kepada Masyarakat Universitas Kristen Petra”. Di akses pada tanggal 1 Maret 2021 dari: Http://smartkids.ftk.uinjambi.ac.id/index.php/smartkids

Triwiyanti, Teguh. 2017. Pengantar Pendidikan. Jakarta: Bumi Aksara. 